\title{
Anti-hepatitis B Virus Activities of Cinobufacini and Its Active Components Bufalin and Cinobufagin in HepG2.2.15 Cells
}

\author{
Xiaoyan Cur, ${ }^{a, b}$ Yoshinori Inagaki,${ }^{b}$ Huanli Xu, ${ }^{b}$ Dongliang Wang, ${ }^{b}$ Fanghua QI,,${ }^{b}$ Norihiro Kokudo, ${ }^{b}$ \\ Dingzhi FANG, ${ }^{a}$ and Wei TANG ${ }^{*}, b$ \\ ${ }^{a}$ Department of Biochemistry and Molecular Biology, West China School of Preclinical and Forensic Medicine, Sichuan \\ University; 17 Section 3, South Renmin Road, Chengdu, Sichuan 610041, China: and ${ }^{b}$ Hepato-Biliary-Pancreatic Surgery \\ Division, Department of Surgery, Graduate School of Medicine, The University of Tokyo; 7-3-1 Hongo, Bunkyo-ku, Tokyo \\ 113-8655, Japan. Received June 2, 2010; accepted July 7, 2010; published online July 14, 2010
}

Cinobufacini (Huachansu) is a Chinese medicine prepared from the skin of Bufo bufo gargarizans Cantor (Bufonidae), which has long been used in traditional Chinese medicine (TCM). The aim of present study was to examine the anti-hepatitis B virus (HBV) activities of cinobufacini and its active components bufalin and cinobufagin in the human HBV-transfected cell line HepG2.2.15. The hepatitis B surface antigen (HBsAg), hepatitis $B$ e antigen (HBeAg), and hepatitis B core-related antigen (HBcrAg) concentrations in cell culture medium were determined by chemiluminescent enzyme immunoassay after HepG2.2.15 cells were respectively treated with different concentrations of cinobufacini, bufalin, and cinobufagin for 3 or $6 \mathrm{~d}$. HBV DNA and mRNA were determined using transcription-mediated amplification and real-time polymerase chain reaction (PCR), respectively. On d 3, cinobufacini at a concentration of $1 \mu \mathrm{g} / \mathrm{ml}$ had no activity against HBV virological markers. However, on d 6, cinobufacini at $1 \mu \mathrm{g} / \mathrm{ml}$ effectively inhibited the secretion of $\mathrm{HBsAg}, \mathrm{HBeAg}$, and $\mathrm{HBcrAg}$ by 29.58, 32.87, and $42.52 \%$. It was more potent than the positive control lamivudine $(100 \mu \mathrm{g} / \mathrm{ml})$. Bufalin and cinobufagin slightly inhibited HBV antigen secretion. Treatment with cinobufacini, bufalin, or cinobufagin had no anti-HBV effect on DNA in cell culture medium. Consistent with the HBV antigen reduction, HBV mRNA expression was markedly inhibited in comparison to the control when HepG2.2.15 cells were treated with cinobufacini, bufalin, or cinobufagin. Results suggested that cinobufacini had more potent activity against HBV antigen secretion than its components bufalin and cinobufagin and this inhibitory role was attributed to the specific inhibition of $\mathrm{HBV}$ mRNA expression.

Key words anti-hepatitis B virus activity; traditional Chinese medicine; cinobufacini; bufalin; cinobufagin

Hepatitis B virus (HBV) infection is a major threat to public health worldwide ${ }^{1,2)}$ and is the leading cause of chronic hepatitis around the world.,4) Hepatitis B may develop into hepatic fibrosis, liver cirrhosis, and hepatocellular carcinoma, accounting for one million deaths annually., ${ }^{5,6)} \mathrm{Al}-$ though safe and effective vaccines for HBV are available, approximately $5-10 \%$ of individuals treated are nonresponders to the hepatitis $\mathrm{B}$ vaccine. ${ }^{7,8)}$ Moreover, there is still no effective treatment for the millions of chronically infected individuals. The therapeutic effect of interferon- $\alpha$ and lamivudine (3TC) is lacking and such treatments may be accompanied by adverse effects and drug resistance following by prolonged administration. ${ }^{9,10)}$ In light of these facts, the discovery and development of novel antiviral drugs for the treatment of HBV is urgently needed. Traditional Chinese medicines (TCMs), widely used to treat hepatitis B in China and many parts of the world, ${ }^{11)}$ may offer good candidates with special antiviral characteristics. They have attracted the attention of researchers striving to identify effective antiviral agents. $^{12)}$

The skin of Bufo bufo gargarizans Cantor (Bufonidae) has long been used in TCM. ${ }^{13,14)}$ Cinobufacini (Huachansu) is a Chinese medicine prepared from this toad skin. ${ }^{15-17)}$ Cinobufacini has been extensively used in clinics to treat a number of diseases, such as malignant tumors, chronic hepatitis B, and systemic and local infection. ${ }^{18)}$ Compared to a control, it significantly increases the negative conversion rates of $\mathrm{HBV}$ virological markers in patients. ${ }^{19)}$ The main pharmacologically active components of cinobufacini are bufadienolides, including bufalin and cinobufagin. ${ }^{20-22)}$ Bufalin has been re- ported to have the ability to reduce HBV production. ${ }^{23)}$ However, the effects of these drugs on the expression of HBV virological markers have not yet been fully investigated and the inhibitory mechanism remains unclear. The present study focused on evaluating anti-HBV activities of cinobufacini and its active components, including bufalin and cinobufagin.

\section{MATERIALS AND METHODS}

Cinobufacini, Bufalin, and Cinobufagin Cinobufacini, which was prepared by extracting $20 \mathrm{~g}$ of the toad skin with boiling water followed by concentration to $1 \mathrm{ml}$, was obtained from Anhui Jinchan Biochemical Co., Ltd. (Anhui, China). Bufalin and cinobufagin (Fig. 1) were purchased from Sigma (St. Louis, MO, U.S.A.). Both compounds were

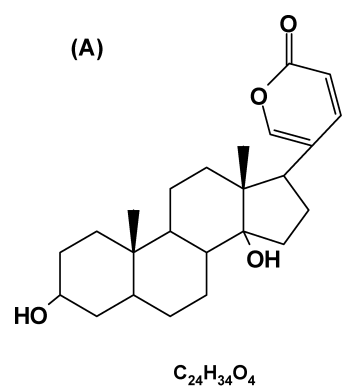

Mol. Wt. 386.53

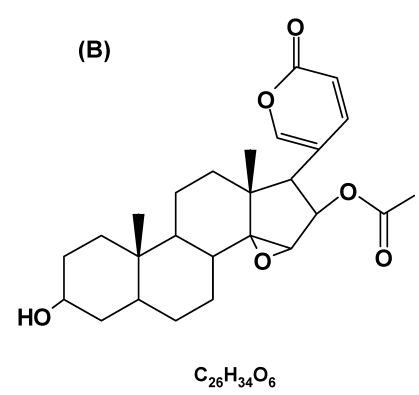

Mol. Wt. 442.54

Fig. 1. Chemical Structures of Bufalin (A) and Cinobufagin (B)

Mol. wt. $=$ molecular weight. 
prepared in dimethylsulfoxide as $1000 \mu \mathrm{M}$ stock solutions and kept at $4{ }^{\circ} \mathrm{C}$. 3TC was from Moravek Biochemicals (Brea, CA, U.S.A.) and served as the positive control. Dilutions of the drugs were performed on the day of medium change. The final concentration of dimethylsulfoxide in the samples was less than $0.01 \%(\mathrm{v} / \mathrm{v})$.

Cell Culture and Treatment The human HBV-transfected cell line HepG2.2.15 ${ }^{24)}$ was maintained in RPMI 1640 medium supplemented with 10\% fetal bovine serum (both from Gibco-Invitrogen, Carlsbad, CA, U.S.A.), 100 unit $/ \mathrm{ml}$ penicillin, $100 \mu \mathrm{g} / \mathrm{ml}$ streptomycin, and $200 \mu \mathrm{g} / \mathrm{ml} \mathrm{G} 418$ (all from Sigma, St. Louis, MO, U.S.A.) at $37^{\circ} \mathrm{C}$ in a humidified incubator with $5 \% \mathrm{CO}_{2}$. Cells were maintained for $24 \mathrm{~h}$ before treatment to reach confluence. The confluent HepG2.2.15 cells were treated with cinobufacini, bufalin, cinobufagin, or 3TC at various concentrations in serum-free medium for $3 \mathrm{~d}$ or $6 \mathrm{~d}$. The culture medium was replaced with a fresh one on $\mathrm{d} 3$, with or without (negative control conditions) different concentrations of drugs or 3TC during the 6-d experiment.

Cytotoxicity Assay HepG2.2.15 cells were seeded in 96well plates at a density of $1.5 \times 10^{4}$ per well and respectively treated with cinobufacini $(1,10,20,50,100$, or $215 \mu \mathrm{g} / \mathrm{ml})$, bufalin $\left(10^{-5}, 10^{-4}, 10^{-3}, 10^{-2}, 10^{-1}\right.$, or $\left.10^{0} \mu \mathrm{M}\right)$, or cinobufagin $\left(10^{-4}, 10^{-3}, 10^{-2}, 10^{-1}, 10^{0}\right.$, or $\left.10 \mu \mathrm{M}\right)$ for 3 or $6 \mathrm{~d}$. The cytotoxicity of different drugs was analyzed with an MTT [3-(4,5-dimethylthiazol-2yl)-2,5-diphenyltetrazolium bromide] assay using the Cell Proliferation Kit I (Roche, Mannheim, Germany) following the manufacturer's instructions. Each experiment was performed in triplicate. The cell viability was expressed as a percentage of the control.

Measurement of HBV Antigens HepG2.2.15 cells were seeded in 6-well plates at a density of $4.5 \times 10^{5}$ per well for measurement of HBV antigens, HBV DNA, and HBV RNA. After incubation with various concentrations of cinobufacini, bufalin, cinobufagin, or 3TC for 3 or $6 \mathrm{~d}$, the culture medium was collected, cell debris was removed, and the result was stored at $-70^{\circ} \mathrm{C}$ until analysis. Hepatitis B surface antigen (HBsAg), hepatitis B e antigen ( $\mathrm{HBeAg}$ ), and hepatitis $\mathrm{B}$ core-related antigen (HBcrAg) in culture supernatants of HepG2.2.15 cells were respectively measured with a Lumipulse $^{\circledR}$ II or I kit or HBcrAg kit (Fuji Rebio, Tokyo, Japan). These kits use a method of chemiluminescent enzyme immunoassay (CLEIA) based on the chemiluminescent capture of specific antigen-antibody reactions.

Quantification of HBV DNA in the Culture Medium The HBV viral load in culture supernatants of HepG2.2.15 cells was quantified with a HBV DNA quantitative kit (SRL, Tokyo, Japan). This kit is based on transcription-mediated amplification and hybridization protection assay. ${ }^{25)}$ Briefly, a mixture of $10 \mu \mathrm{l}$ of cell culture supernatants or amplification standards, Sample Diluent I, Sample Diluent II, and Primer Reagent and $50 \mu \mathrm{l}$ of oil were placed in a reaction tube. The tube was heated at $95^{\circ} \mathrm{C}$ for $10 \mathrm{~min}$ and then incubated at $37^{\circ} \mathrm{C}$ for $5 \mathrm{~min}$. Neutralization reagent and reconstituted amplification reagent solution were added and the reaction mixture was incubated at $37^{\circ} \mathrm{C}$ for $3 \mathrm{~h}$. RNA amplicons were detected with a hybridization protection assay. The measurement range was 3.7-8.7 log genome equivalent/ml (LGE/ $\mathrm{ml})$.

Determination of HBV RNA Total RNA was isolated from HepG2.2.15 cells using Trizol reagent (Invitrogen) in accordance with the manufacturer's instructions. The mRNA was then reverse-transcribed to make cDNA using a QuantiTect Rev. Transcription Kit (Qiagen, GmbH, Germany) and oligo dT primer following the manufacturer's instructions. The cDNA was quantified using the Thermal Cycler Dice ${ }^{\mathrm{TM}}$ Real Time System (Takara, Shiga, Japan). The polymerase chain reaction (PCR) was performed using primers (synthesized by Invitrogen): HBV surface region F 5'-GCCAAAATTCGCAGTCC-3' and R 5'-ACGGGCAACATACCTT3'; HBV core region F 5'-AGACCACCAAATGCCCCTAT3' and R 5'-GATCTTCTGCGACGCGGCGA-3'; glyceraldehyde-3-phosphate dehydrogenase (GAPDH) (internal control) F (h) 5'-AGGGGTCATTgATGGCAACAATATCCA-3' and R (h) 5'-TTTACCAGAGTTAAAAGCAGCCCTGGTG$3^{\prime}$. Controls included water blanks and RNA extracts that were not subjected to reverse transcription. A series of dilutions of Topo-HBV plasmid containing HBV genes and Topo-GAPDH plasmid containing GAPDH cDNA were used to create standard curves for quantifying $\mathrm{HBV}$ and GAPDH mRNA levels, respectively. These plasmid concentrations were as follows (copy/ $\mu \mathrm{l}): 10^{2}, 10^{3}, 10^{4}, 10^{5}, 10^{6}, 10^{7}$, and $10^{8}$. Taq readymix with SYBR green (Sigma, St. Louis, MO, U.S.A.) was used to amplify and detect DNA during the reaction. Thermal cycling parameters for the HBV core region and GAPDH consisted of a hot start for $2 \mathrm{~min}$ at $94{ }^{\circ} \mathrm{C}$ followed by 40 cycles of $94^{\circ} \mathrm{C}$ for $15 \mathrm{~s}, 60^{\circ} \mathrm{C}$ for $30 \mathrm{~s}$, and then $72^{\circ} \mathrm{C}$ for $40 \mathrm{~s}$. Thermal cycling parameters for the HBV surface region consisted of a hot start for $2 \mathrm{~min}$ at $94^{\circ} \mathrm{C}$ followed by 45 cycles of $94^{\circ} \mathrm{C}$ for $15 \mathrm{~s}, 58^{\circ} \mathrm{C}$ for $30 \mathrm{~s}$, and then $72^{\circ} \mathrm{C}$ for $30 \mathrm{~s}$. Specificity of the PCR products was verified by melting curve analysis and agarose gel electrophoresis.

Statistical Analysis All the items determined in this study were repeated at least three times, and the results were expressed as mean \pm S.D. Statistical significance was determined using analysis of variance (ANOVA) or a rank sum test. Differences were considered significant at $p<0.05$.

\section{RESULTS}

Cytotoxic Effects of Cinobufacini, Bufalin, and Cinobufagin The viabilities of the HepG2.2.15 cells in the presence of various concentrations of cinobufacini, bufalin, and cinobufagin were examined with a MTT assay. The results showed that cinobufacini concentrations below $20 \mu \mathrm{g} / \mathrm{ml}$, bufalin concentrations below $10^{-2} \mu \mathrm{M}$, and cinobufagin concentrations below $10^{-1} \mu \mathrm{M}$ had no significant toxicity to HepG2.2.15 cells (Fig. 2). Cinobufacini, bufalin, and cinobufagin significantly inhibited the growth of HepG2.2.15 cells at concentrations above $20 \mu \mathrm{g} / \mathrm{ml}, 10^{-2} \mu \mathrm{M}$, and $10^{-1} \mu \mathrm{M}$, respectively. The cytotoxicity of these drugs was examined to determine the treatment concentrations in the following HepG2.2.15 cell culture experiments.

Effects of Cinobufacini on HBV Antigens and DNA In this anti-HBV assay, HepG2.2.15 cells were treated with different concentrations of cinobufacini for 3 or $6 \mathrm{~d}$. On d 3 , cinobufacini at a concentration of $1 \mu \mathrm{g} / \mathrm{ml}$ had no activity against HBV virological markers. However, on d 6, cinobufacini at a concentration of $1 \mu \mathrm{g} / \mathrm{ml}$ significantly reduced the secretion of $\mathrm{HBsAg}, \mathrm{HBeAg}$, and $\mathrm{HBcrAg}$ in the culture medium (Table 1). This concentration of cinobufacini exhib- 
ited more potent activity than the positive control 3TC $(100 \mu \mathrm{g} / \mathrm{ml})$ in terms of the inhibition of HBV antigen secretion. It respectively decreased secretion of $\mathrm{HBsAg}, \mathrm{HBeAg}$, and HBcrAg by $29.58,32.87$, and $42.52 \%$ while $3 \mathrm{TC}$ at $100 \mu \mathrm{g} / \mathrm{ml}$ respectively reduced secretion of these antigens by $21.88,20.81$, and $17.38 \%$. Cinobufacini at $20 \mu \mathrm{g} / \mathrm{ml}$ also inhibited secretion of HBV antigens. There were no significant differences between cinobufacini treatment and the control in terms of the HBV DNA levels in the culture medium.

(A)

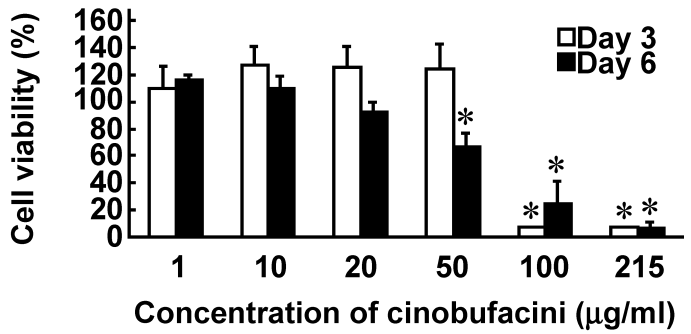

(B)

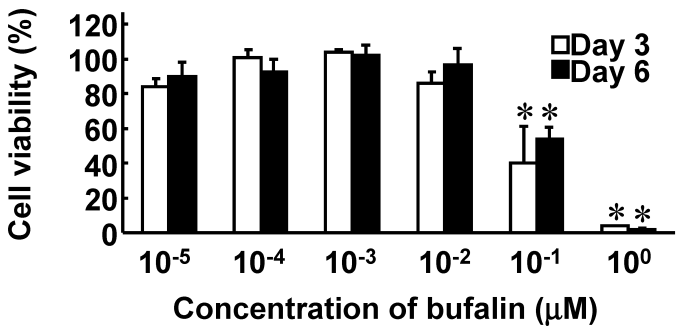

(C)

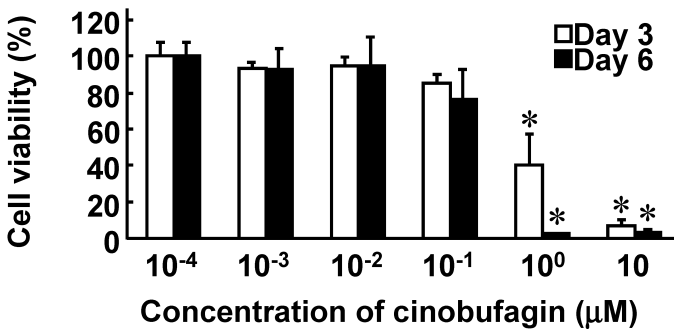

Fig. 2. MTT Cytotoxicity Assay Results

(A) Cinobufacini, (B) bufalin, (C) cinobufagin. The cell viability was expressed as a percentage of the control. Data shown represent the mean values ( \pm S.D.) based on three independent experiments. Symbols represent statistical significance. $* p<0.05 v s$. control.
Effects of Bufalin on HBV Antigens and DNA Treatment of HepG2.2.15 cells with bufalin resulted in a reduction of HBsAg, HBeAg, and HBcrAg secretion (Table 2). After treatment for $6 \mathrm{~d}$, bufalin at a concentration of $10^{-4} \mu \mathrm{M}$ significantly inhibited secretion of HBcrAg at a rate of $19.58 \%$. This concentration of bufalin was more potent than the positive control 3TC at inhibiting HBcrAg secretion. Based on this analysis, bufalin has greater inhibitory activity with respect to $\mathrm{HBeAg}$ than to $\mathrm{HBsAg}$. Like cinobufacini, bufalin exhibited no inhibitory effect on HBV DNA in culture medium (Table 2).

Effects of Cinobufagin on HBV Antigens and DNA After 3 or $6 \mathrm{~d}$ of incubation with cinobufagin, secretion of $\mathrm{HBeAg}$ and HBcrAg in the culture medium was slightly less than that with the control (Table 3). Moreover, cinobufagin at a concentration of $10^{-3} \mu \mathrm{M}$ on $\mathrm{d} 3$ exhibited the same potent activity as the positive control $3 \mathrm{TC}(100 \mu \mathrm{g} / \mathrm{ml})$ in terms of the inhibition of $\mathrm{HBeAg}$ secretion. Cinobufagin was also found to have relatively greater inhibition of $\mathrm{HBeAg}$ than HBsAg. Consistent with the inhibitory effects of cinobufacini and bufalin, cinobufagin treatment led to no significant antiviral activity in HBV DNA release to the culture medium in comparison to the control (Table 3 ).

Effects of Cinobufacini, Bufalin, and Cinobufagin on HBV mRNA Expression To determine if the effects of cinobufacini, bufalin, and cinobufagin on $\mathrm{HBsAg}, \mathrm{HBeAg}$, and $\mathrm{HBcrAg}$ secretion were induced by decreases in HBV RNA levels, real-time PCR analysis was performed using total RNA isolated from HepG2.2.15 cells. When treated with cinobufacini at a concentration of $1 \mu \mathrm{g} / \mathrm{ml}$ for $6 \mathrm{~d}$, inhibition of HBV mRNA was observed with a $56.08 \%$ reduction in the HBV surface/GAPDH mRNA ratio and a $65.12 \%$ reduction in the $\mathrm{HBV}$ core/GAPDH mRNA ratio in comparison to controls (Fig. 3). Similarly, incubation with bufalin at $10^{-4} \mu \mathrm{M}$ and cinobufagin at $10^{-3} \mu \mathrm{M}$ led to significant reductions in HBV mRNA from the surface and core regions. These results showed that the HBV mRNA expression was markedly inhibited in comparison to the control when HepG2.2.15 cells were treated with cinobufacini, bufalin, or cinobufagin at lower concentrations. These findings revealed that the inhibitory effects of cinobufacini, bufalin, and cinobufagin on the secretion of HBV antigens would be induced by the specific inhibition of HBV mRNA expression.

Table 1. Inhibitory Effects of Cinobufacini on the Expression of HBV Antigens and DNA in HepG2.2.15 Cells on D 3 and 6

\begin{tabular}{|c|c|c|c|c|c|c|c|c|}
\hline \multirow{2}{*}{ Samples } & \multicolumn{2}{|c|}{ HBsAg } & \multicolumn{2}{|c|}{$\mathrm{HBeAg}$} & \multicolumn{2}{|c|}{ HBcrAg } & \multicolumn{2}{|c|}{ HBV-DNA } \\
\hline & $(\mathrm{COI}) \times 10^{2}$ & Inhibition (\%) & $(\mathrm{COI}) \times 10^{2}$ & Inhibition (\%) & $(\mathrm{kU} / \mathrm{ml}) \times 10^{2} \mathrm{In}$ & Inhibition (\%) & (LGE/ml) & Inhibition (\%) \\
\hline \multicolumn{9}{|l|}{ D 3} \\
\hline Control & $7.09 \pm 0.09$ & - & $1.06 \pm 0.25$ & - & $18.46 \pm 0.24$ & - & $5.4 \pm 0.10$ & - \\
\hline $3 \mathrm{TC}(100 \mu \mathrm{g} / \mathrm{ml})$ & $6.49 \pm 0.18 *$ & 8.34 & $0.98 \pm 0.29$ & 7.71 & $20.22 \pm 0.05$ & - & $5.2 \pm 0.17$ & 36.90 \\
\hline Cinobufacini $(20 \mu \mathrm{g} / \mathrm{ml})$ & $7.51 \pm 0.23$ & - & $1.21 \pm 0.38$ & - & $17.48 \pm 0.24 *, \#$ & 5.31 & $5.5 \pm 0.17$ & - \\
\hline Cinobufacini $(1 \mu \mathrm{g} / \mathrm{ml})$ & $8.25 \pm 0.06$ & - & $1.21 \pm 0.28$ & - & $23.60 \pm 0.32$ & - & $5.5 \pm 0.20$ & - \\
\hline \multicolumn{9}{|l|}{ D 6} \\
\hline Control & $12.86 \pm 0.22$ & - & $1.73 \pm 0.32$ & - & $58.46 \pm 0.60$ & - & $5.9 \pm 0.26$ & - \\
\hline $3 \mathrm{TC}(100 \mu \mathrm{g} / \mathrm{ml})$ & $10.05 \pm 0.22 *$ & 21.88 & $1.37 \pm 0.17^{*}$ & 20.81 & $48.30 \pm 0.40 *$ & 17.38 & $5.1 \pm 0.10^{*}$ & 84.15 \\
\hline Cinobufacini $(20 \mu \mathrm{g} / \mathrm{ml})$ & $11.69 \pm 0.49 *$ & 9.09 & $1.63 \pm 0.12$ & 5.33 & $53.14 \pm 0.55^{*}$ & 9.10 & $5.9 \pm 0.00$ & - \\
\hline Cinobufacini $(1 \mu \mathrm{g} / \mathrm{ml})$ & $9.05 \pm 0.32 *, \#$ & 29.58 & $1.16 \pm 0.18^{*}$ & 32.87 & $33.61 \pm 0.14^{*, \#}$ & 42.52 & $5.9 \pm 0.20$ & - \\
\hline
\end{tabular}

LGE/ml: log genome equivalent $/ \mathrm{ml}$. Data shown represent the mean values ( \pm S.D.) based on three independent experiments. Symbols represent statistical significance. $* p<0.05$ vs. control; $\# p<0.05$ vs. $3 \mathrm{TC}(100 \mu \mathrm{g} / \mathrm{ml})$. 
Table 2. Inhibitory Effects of Bufalin on the Expression of HBV Antigens and DNA in HepG2.2.15 Cells on D 3 and 6

\begin{tabular}{|c|c|c|c|c|c|c|c|c|}
\hline \multirow{2}{*}{ Samples } & \multicolumn{2}{|c|}{ HBsAg } & \multicolumn{2}{|c|}{ HBeAg } & \multicolumn{2}{|c|}{ HBcrAg } & \multicolumn{2}{|c|}{ HBV-DNA } \\
\hline & $(\mathrm{COI}) \times 10^{2}$ & Inhibition (\%) & $(\mathrm{COI}) \times 10^{2}$ & Inhibition (\%) & $(\mathrm{kU} / \mathrm{ml}) \times 10^{2}$ & Inhibition (\%) & (LGE/ml) & Inhibition $(\%)$ \\
\hline \multicolumn{9}{|l|}{ D 3} \\
\hline Control & $7.09 \pm 0.09$ & - & $1.06 \pm 0.25$ & - & $18.46 \pm 0.24$ & - & $5.4 \pm 0.10$ & - \\
\hline 3TC $(100 \mu \mathrm{g} / \mathrm{ml})$ & $6.49 \pm 0.18 *$ & 8.34 & $0.98 \pm 0.29$ & 7.71 & $20.22 \pm 0.05$ & - & $5.2 \pm 0.17$ & 36.90 \\
\hline Bufalin $\left(10^{-2} \mu \mathrm{M}\right)$ & $6.06 \pm 0.17 *$ & 14.42 & $0.73 \pm 0.23 *$ & 30.95 & $19.06 \pm 0.21$ & - & $5.6 \pm 0.20$ & - \\
\hline Bufalin $\left(10^{-4} \mu \mathrm{M}\right)$ & $7.98 \pm 0.40$ & - & $1.16 \pm 0.47$ & - & $21.92 \pm 0.43$ & - & $5.5 \pm 0.10$ & - \\
\hline \multicolumn{9}{|l|}{ D 6} \\
\hline Control & $12.86 \pm 0.22$ & - & $1.73 \pm 0.32$ & - & $58.46 \pm 0.60$ & - & $5.9 \pm 0.26$ & - \\
\hline 3TC $(100 \mu \mathrm{g} / \mathrm{ml})$ & $10.05 \pm 0.22 *$ & 21.88 & $1.37 \pm 0.17 *$ & 20.81 & $48.30 \pm 0.40^{*}$ & 17.38 & $5.1 \pm 0.10^{*}$ & 84.15 \\
\hline Bufalin $\left(10^{-2} \mu \mathrm{M}\right)$ & $13.03 \pm 0.33$ & - & $1.84 \pm 0.17$ & - & $55.15 \pm 0.49 *$ & 5.67 & $5.9 \pm 0.10$ & - \\
\hline Bufalin $\left(10^{-4} \mu \mathrm{M}\right)$ & $13.51 \pm 1.03$ & - & $1.53 \pm 0.23$ & 11.36 & $47.01 \pm 0.23^{*, \#}$ & 19.58 & $5.9 \pm 0.10$ & - \\
\hline
\end{tabular}

LGE/ml: log genome equivalent $/ \mathrm{ml}$. Data shown represent the mean values ( \pm S.D.) based on three independent experiments. Symbols represent statistical significance $* p<0.05$ vs. control; $\# p<0.05$ vs. $3 \mathrm{TC}(100 \mu \mathrm{g} / \mathrm{ml})$.

Table 3. Inhibitory Effects of Cinobufagin on the Expression of HBV Antigens and DNA in HepG2.2.15 Cells on D 3 and 6

\begin{tabular}{|c|c|c|c|c|c|c|c|c|}
\hline \multirow{2}{*}{ Samples } & \multicolumn{2}{|c|}{$\mathrm{HBsAg}$} & \multicolumn{2}{|c|}{$\mathrm{HBeAg}$} & \multicolumn{2}{|c|}{ HBcrAg } & \multicolumn{2}{|c|}{ HBV-DNA } \\
\hline & $(\mathrm{COI}) \times 10^{2}$ & Inhibition $(\%)$ & $(\mathrm{COI}) \times 10^{2}$ & Inhibition $(\%)$ & $(\mathrm{kU} / \mathrm{ml}) \times 10^{2}$ & Inhibition (\%) & (LGE/ml) & Inhibition $(\%)$ \\
\hline \multicolumn{9}{|l|}{ D 3} \\
\hline Control & $7.09 \pm 0.09$ & - & $1.06 \pm 0.25$ & - & $18.46 \pm 0.24$ & - & $5.4 \pm 0.10$ & - \\
\hline $3 \mathrm{TC}(100 \mu \mathrm{g} / \mathrm{ml})$ & $6.49 \pm 0.18^{*}$ & 8.34 & $0.98 \pm 0.29$ & 7.71 & $20.22 \pm 0.05$ & - & $5.2 \pm 0.17$ & 36.90 \\
\hline Cinobufagin $\left(10^{-1} \mu \mathrm{M}\right)$ & $7.87 \pm 0.09$ & - & $1.19 \pm 0.28$ & - & $23.97 \pm 0.33$ & - & $5.4 \pm 0.17$ & - \\
\hline Cinobufagin $\left(10^{-3} \mu \mathrm{M}\right)$ & $7.16 \pm 0.17$ & - & $0.98 \pm 0.24$ & 8.28 & $17.91 \pm 0.36^{*, \#}$ & 3.01 & $5.4 \pm 0.20$ & - \\
\hline \multicolumn{9}{|l|}{ D 6} \\
\hline Control & $12.86 \pm 0.22$ & - & $1.73 \pm 0.32$ & - & $58.46 \pm 0.60$ & - & $5.9 \pm 0.26$ & - \\
\hline 3TC $(100 \mu \mathrm{g} / \mathrm{ml})$ & $10.05 \pm 0.22^{*}$ & 21.88 & $1.37 \pm 0.17 *$ & 20.81 & $48.30 \pm 0.40^{*}$ & 17.38 & $5.1 \pm 0.10 *$ & 84.15 \\
\hline Cinobufagin $\left(10^{-1} \mu \mathrm{M}\right)$ & $14.11 \pm 0.45$ & - & $1.66 \pm 0.13$ & 3.77 & $56.98 \pm 0.50 *$ & 2.53 & $6.0 \pm 0.17$ & - \\
\hline Cinobufagin $\left(10^{-3} \mu \mathrm{M}\right)$ & $12.97 \pm 0.34$ & - & $1.60 \pm 0.11$ & 7.01 & $54.27 \pm 0.35^{*}$ & 7.16 & $6.0 \pm 0.26$ & - \\
\hline
\end{tabular}

LGE/ml: log genome equivalent $/ \mathrm{ml}$. Data shown represent the mean values $( \pm$ S.D.) based on three independent experiments. Symbols represent statistical significance $* p<0.05$ vs. control; $\# p<0.05$ vs. $3 \mathrm{TC}(100 \mu \mathrm{g} / \mathrm{ml})$.

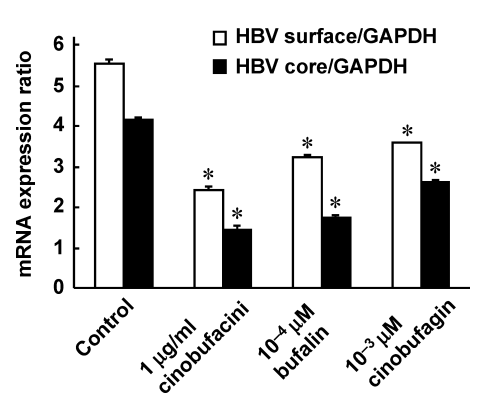

Fig. 3. Effects of Cinobufacini, Bufalin, and Cinobufagin on the mRNA Levels of HBV from the Surface and Core Regions in HepG2.2.15 Cells on D 6

Data shown represent the mean values $( \pm$ S.D.) based on three independent experiments. Symbols represent statistical significance. $* p<0.05 v$. control.

\section{DISCUSSION}

Cinobufacini, a Chinese medicine derived from the toad skin of Bufo bufo gargarizans Cantor (Bufonidae), has long been used in the treatment of hepatitis B in China. ${ }^{18,19,26)}$ Therefore, cinobufacini has been considered to have the efficacy in the management of HBV infection. In the present study, the anti-HBV activity of cinobufacini was evaluated in the HepG2.2.15 cell line. Cinobufacini at a concentration of $1 \mu \mathrm{g} / \mathrm{ml}$ exhibited more potent activity than the positive control $3 \mathrm{TC}(100 \mu \mathrm{g} / \mathrm{ml})$ in terms of the inhibition of HBV antigen secretion after treatment of HepG2.2.15 cells for $6 \mathrm{~d}$.
It inhibited the secretion of $\mathrm{HBsAg}, \mathrm{HBeAg}$, and $\mathrm{HBcrAg}$ by $29.58,32.87$, and $42.52 \%$, respectively, while $3 \mathrm{TC}$ at $100 \mu \mathrm{g} / \mathrm{ml}$ decreased secretion of these three antigens by $21.88,20.81$, and $17.38 \%$, respectively. This effect of $3 \mathrm{TC}$ was consistent with that noted in a previous report. ${ }^{27)}$ Moreover, no cytotoxicity was observed with cinobufacini at $1 \mu \mathrm{g} / \mathrm{ml}$. These results clearly revealed that cinobufacini had anti-HBV properties and that its inhibitory activities were not induced by cytotoxicity.

Many reports have noted that the main pharmacologically active components of cinobufacini include bufalin and cinobufagin. ${ }^{20,21)}$ Therefore, the present study also analyzed the anti-HBV activities of bufalin and cinobufagin. The concentrations of bufalin and cinobufagin in cinobufacini at $20 \mathrm{~g} / \mathrm{ml}$ are $12.84 \mu \mathrm{g} / \mathrm{ml}$ and $6.133 \mu \mathrm{g} / \mathrm{ml}$, respectively. ${ }^{28)}$ Thus, $1 \mu \mathrm{g} / \mathrm{ml}$ of cinobufacini contained $6.42 \times 10^{-7} \mu \mathrm{g} / \mathrm{ml}$ of bufalin, which was lower than $10^{-4} \mu \mathrm{M}\left(3.87 \times 10^{-5} \mu \mathrm{g} / \mathrm{ml}\right)$ of pure bufalin. That is to say, although the bufalin level in cinobufacini at $1 \mu \mathrm{g} / \mathrm{ml}$ was less than bufalin at $10^{-4} \mu \mathrm{M}$, the effect of cinobufacini at $1 \mu \mathrm{g} / \mathrm{ml}$ was more potent than that of bufalin at $10^{-4} \mu \mathrm{M}$ in terms of inhibiting HBV antigen secretion. Similarly, the inhibitory activity of cinobufacini at $1 \mu \mathrm{g} / \mathrm{ml}$ (containing $3.07 \times 10^{-7} \mu \mathrm{g} / \mathrm{ml}$ of cinobufagin) was greater than cinobufagin at $10^{-3} \mu \mathrm{M}\left(4.43 \times 10^{-4} \mu \mathrm{g} / \mathrm{ml}\right)$. These data strongly suggested that cinobufacini was more potent than its components bufalin and cinobufagin in terms of inhibiting HBV.

The anti-HBV activity of bufalin has been reported. ${ }^{23)}$ 
This report only detected HBsAg among HBV antigens and showed that treatment with bufalin for $21 \mathrm{~d}$ decreased HBsAg secretion and increased HBV DNA level in the culture medium. The discrepancy in the anti-HBV effect of this report and the present study could be attributed to different time course of treatment and different bufalin concentrations. The effects of cinobufacini, bufalin, and cinobufagin at lower concentrations were respectively more potent than those of these three drugs at higher concentrations in terms of inhibiting HBV antigen secretion. This result could be explained by the cytotoxic effects that were induced by these three drugs at some concentrations, such as $8 \%$ of toxic effect induced by cinobufacini at $20 \mu \mathrm{g} / \mathrm{ml}$ on $\mathrm{d} 6$. The impairment of cells might affect the production and release of $\mathrm{HBV}$ particles, which were decreased or increased.

In clinical application, the side effects that may be related to cinobufacini include hematologic, gastrointestinal, mucocutaneous, and cardiovascular symptoms, but these adverse effects are mild. ${ }^{18,29)}$ A clinical study demonstrated that $73 \%$ of patients administered with cinobufacini had no toxicities greater than grade I and no grade III or IV toxicities were observed. ${ }^{30)}$ Moreover, although cinobufacini contains cardiac glycosides (bufalin, cinobufagin, etc.), significant cardiac toxicity was not observed. ${ }^{18,30}$ The results of present study suggested that cinobufacini at lower concentrations without toxicity possessed potent anti-HBV activity. Therefore, the anti-HBV effect induced by cinobufacini could be achieved without toxicity in humans.

In the present study, cinobufacini, bufalin, and cinobufagin inhibited HBV antigen secretion. These roles may take place at the transcription and post-transcription levels. ${ }^{31}$ ) Therefore, the HBV mRNA level was determined in HepG2.2.15 cells. The results revealed that HBV antigen inhibition by cinobufacini, bufalin, and cinobufagin was attributed to the specific inhibition of HBV mRNA expression. The decreases in HBV mRNA levels may be induced by the decreased synthesis and the increased degradation of HBV mRNA, which is regulated by enhancers and promoters of HBV, several nuclear hormone receptors and their physiological regulators, RNA-binding proteins, and nuclear RNases, etc. ${ }^{32)}$ Therefore, the inhibition of HBV mRNA expression by cinobufacini, bufalin, and cinobufagin might be due to the effects of these three drugs on these cis elements, nuclear hormone receptors and their physiological regulators, RNAbinding proteins, and RNases.

In conclusion, the present study demonstrated that cinobufacini possessed potent anti-HBV activity in vitro. It was more effective than its components bufalin and cinobufagin at inhibiting the secretion of HBV antigens. These inhibitory roles of cinobufacini, bufalin, and cinobufagin might take place at the transcription and post-transcription levels. The present findings suggested that cinobufacini could effectively inhibit HBV antigen secretion in vitro. Therefore, cinobufacini warrants further investigation.

Acknowledgements This study was funded by a Grantin-Aid for Scientific Research (B) from the Japan Society for the Promotion of Science (JSPS, No. 21390373). The authors wish to thank Dr. Nobuyoshi Akimitsu (The University of Tokyo) for providing the Thermal Cycler Dice ${ }^{\mathrm{TM}}$ Real Time System for this study.

\section{REFERENCES}

1) Simonetti J., Bulkow L., McMahon B. J., Homan C., Snowball M., Negus S., Williams J., Livingston S. E., Hepatology, 51, 1-7 (2010).

2) Ochirbat T., Ali M., Pagbajab N., Erkhembaatar L. O., Budbazar E., Sainkhuu N., Tudevdorj E., Kuroiwa C., Biosci. Trends, 2, 68-74 (2008).

3) Ocama P., Opio C. K., Lee W. M., Am. J. Med., 118, 1413.e151413.e22 (2005).

4) Zhang H. H., Mei M. H., Fei R., Liu F., Wang J. H., Liao W. J., Qin L. L., Wei L., Chen H. S., J. Viral Hepat., 17, 34-43 (2010).

5) Mendy M. E., Welzel T., Lesi O. A., Hainaut P., Hall A. J., Kuniholm M. H., McConkey S., Goedert J. J., Kaye S., Rowland-Jones S., Whittle H., Kirk G. D., J. Viral Hepat., 17, 115-122 (2010).

6) Rokuhara A., Sun X., Tanaka E., Kimura T., Matsumoto A., Yao D., Yin L., Wang N., Maki N., Kiyosawa K., J. Gastroenterol. Hepatol., 20, 1726-1730 (2005)

7) Cardell K., Akerlind B., Sällberg M., Frydén A., J. Infect. Dis., 198, 299-304 (2008).

8) Li X., Xu W. F., Drug Discov. Ther, 1, 84-85 (2007).

9) Feld J., Locarnini S., J. Clin. Virol., 25, 267-283 (2002)

10) Perrillo R. P., Semin. Liver Dis., 25, 20-28 (2005).

11) Zhang L., Wang G., Hou W., Li P., Dulin A., Bonkovsky H. L., Hepatology, 51, 690-698 (2010).

12) Stickel F., Schuppan D., Dig. Liver Dis., 39, 293-304 (2007).

13) Chen K. K., Kovaríková A., J. Pharm. Sci., 56, 1535-1541 (1967).

14) Zhang J., Sun Y., Liu J. H., Yu B. Y., Xu Q., Bioorg. Med. Chem. Lett., 17, 6062-6065 (2007)

15) Wang J., Jin Y., Xu Z., Zheng Z., Wan S., Exp. Biol. Med. (Maywood), 234, 566-572 (2009).

16) Qi F. H., Li A. Y., Lv H., Zhao L., Li J. J., Gao B., Tang W., Drug Discov. Ther, 2, 339-343 (2008).

17) Dai L. P., Gao H. M., Wang Z. M., Wang W. H., Yao Xue Xue Bao, 42, 858-861 (2007).

18) Lan Y. N., Chin. J. Clin. Hepatol., 18, 374-375 (2002).

19) Wang W. M., Li R. H., Mod. J. Integr. Tradit. Chin. West. Med., 10 $1632-1633$ (2001)

20) Sui Y. H., Yin S. C., Xie J. M., Gao B., Ling C. Q., Acad. J. Sec. Mil. Med. Univ., 24, 393-395 (2003).

21) Dai L. P., Wang Z. M., Gao H. M., Jiang X., Ding G. Z., Zhongguo Zhong Yao Za Zhi, 32, 224-226 (2007).

22) Wang D. L., Qi F. H., Xu H. L., Inagaki Y., Orihara Y., Sekimizu K., Kokudo N., Wang F. S., Tang W., Mol. Med. Report, 3, 717-722 (2010).

23) Romero M. R., Efferth T., Serrano M. A., Castaño B., Macias R. I., Briz O., Marin J. J., Antiviral Res., 68, 75-83 (2005).

24) Sells M. A., Chen M. L., Acs G., Proc. Natl. Acad. Sci. U.S.A., 84, 1005-1009 (1987)

25) Kamisango K., Kamogawa C., Sumi M., Goto S., Hirao A., Gonzales F., Yasuda K., Iino S., J. Clin. Microbiol., 37, 310-314 (1999).

26) Ji G. S., Chin. J. Integr. Tradit. West. Med. Liver Dis., 15, 53-54 (2005).

27) Wang S., Li J., Huang H., Gao W., Zhuang C., Li B., Zhou P., Kong D., Biol. Pharm. Bull., 32, 132-135 (2009).

28) Su Y. H., Huang X. Q., Zhang D. Z., Zhang Y. N., Xie J. M., Ling C. Q., Chin. Trad. Pat. Med., 25, 24-27 (2003).

29) Wang T. T., Xu G. X., Int. J. Ophthalmol., 9, 1330-1333 (2009).

30) Meng Z. Q., Yang P. Y., Shen Y. H., Bei W. Y., Zhang Y., Ge Y. Q., Newman R. A., Cohen L., Liu L. M., Thornton B., Chang D. Z., Liao Z. X., Kurzrock R., Cancer, 115, 5309-5318 (2009).

31) Zhou Z., Zhang Y., Ding X. R., Chen S. H., Yang J., Wang X. J., Jia G. L., Chen H. S., Bo X. C., Wang S. Q., Antiviral Res., 74, 59-64 (2007).

32) Heise T., Guidotti L. G., Chisari F. V., J. Virol., 75, 6874-6883 (2001). 